\title{
MISCELLANEOUS.
}

\section{Acclimatization of Parrots at Northrepps Hall, Norfolle.}

[At the recent Meeting of the British Association, the Members, among other invitations, were invited to pay a visit to Northrepps Hall, the residence of the Dowager Lady Buxton. While partaking of the hospitality provided by the accomplished hostess, the guests were delighted and astonished by the parrots that darted in and out among the trees or flew over their heads across the lawn, their brilliant plumage glancing in the radiance of the setting sun. After tea, Mr. Charles Buxton, M.P., read the following paper. We are sorry to learn that these birds, which at one time amounted to nearly fifty, have been reduced now to some twenty-four, owing to the vicious propensity of gamekeepers and so-called sportsmen to wantonly destroy every stranger that may come across them.]

I HAVE undertaken to tell you a little about the experiment that has been tried here of letting parrots fly wild about the place; but though it has been a source of great interest and amusement to us, I much fear that there is very little to relate that could be thought worthy of the attention, even in their holiday moments, of an Association for the Advancement of Science. Nor can I honestly say that the attempt to acclimatize these birds (that is to say, to establish them as an addition to our English fauna) has in that respect been attended by success. It is true that they have several times made nests, and on five of these occasions the young have been brought to maturity; and were it not "for those vile guns," the birds would flourish extremely; for illness and death from natural causes would seem to be almost unknown among them. But, unhappily, they share in many of the characteristics of human nature, and in this one, above all, that they do not know when they are well off, and every now and then they are seized with a desire to see the world, and take flights to a distance, twelve or fifteen miles perhaps, and sometimes much more; and then they are almost sure to fall a prey to some gamekeeper or lad who is keeping crows, and who is astonished by seeing these brilliant apparitions among the trees. As regards their breeding, a pair of cockatoos led the way by most unsuccessfully attempting to make a nest in one of the chimneys; before it was half finished it gave way, and the nest and cockatoos fell to the bottom. It being summer time, they were only discovered after spending a day and a night among the soot, and when they were brought out they looked like two dwarf chimney sweeps. They persevered, however, and made another nest in one of the boxes that had been hung against the gables of the house in hopes of such an event. They laid two eggs; but though the hen cockatoo sat most perseveringly till September, it was all in vainthe eggs were addled. Afterwards a pair of green parrots, a cock of the Amazonian and a hen of the Honduras breed, made a nest in one of the boxes, and brought up a young one; but when he was 
nearly fledged, one of the cockatoos thought it right to murder him. The year after, the same pair brought up two children, and it was really a beautiful sight to see the family party flying about, always together, and living on the most loving terms; but the mother and her eldest son both, unhappily, were shot. Afterwards one of the common white cockatoos and the hen Leadbeater (a very large rosecoloured cockatoo) dug out their own nest in the rotten branch of an acacia tree, laid two eggs, and brought up the young birds. These hybrids are very handsome, but do not resemble either of the parents, having beautiful crests of a red-orange-colour. Otherwise they are perfectly white. The parent birds were so pleased with the success of this experiment that last year they repeated it, and brought up three young ones, thus making up a flock of seven with the two firstborn. Unluckily one of them was shot at in the winter, and came home severely wounded; after which the other birds would not permit him to associate with them, and he always lived in a bush near the house, quite apart from the rest. One day I moved him into the garden, upon which some of the other cockatoos (not, however, his own relations) fell upon him the moment my back was turned, and killed him-one of those traits of character which, as I said just now, these birds, and, in fact, most wild animals, share with human nature in their general dislike of cripples. Another of them was also injured; so I took him away to Surrey, where, in spite of his broken wing and broken leg, an old cockatoo befriended him, and treats him as her own son. This year we hoped that the same pair would nest again; but unluckily, a pair of grey parrots anticipated them in the possession of the hollow branch, and, having made a nest in it, brought up two young grey parrots, and which are afflicted with awful tempers. The maternal instinct of another pair of grey parrots took a very absurd form this year. A cat made her lodging in one of the nestboxes, and brought up her kittens in it, and two of the grey parrots, who had not been industrious enough to lay eggs and have a family of their own, were seized with the idea that these kittens were their children. They kept up a constant warfare with the old cat; and whenever she left the box, one of them used to get in and sit with the kittens, and they were constantly in close attendance, even when the mother cat was at home. When the cockatoos I have spoken of had their nest in the acacia tree, it was very ridiculous to see the extravagant interest taken in the matter by the others of the same species. They used to sit most of the day on the branches, just above the nest, and whenever the parent bird flew out, she was attended by a troop of the others, screaming horrible acclamations in her honour. There is an immense deal of originality about this race of birds. They have none of the common-place humdrum mediocrity of birds in general. Their curiosity is unbounded, and they evidently look on man and his doings with the keenest interest, mingled with surprise, and with, perhaps, just a soupcon of contempt. There is, moreover, strongly marked individual character among them. No two of them behave exactly in the same manner. I think 
the large white cockatoo with the broad white crest is the most intelligent of the lot. I had one of them whom I wished to keep chained to a perch; but though a first-rate London locksmith tried everything his ingenuity could suggest, the cockatoo beat him utterly. Without breaking it, he contrived to open the ring or other contrivance for holding him, with his beak, though one or two of them must, one would have thought, have required great study to understand.

The experiment of acclimatizing parrots has been tried on a somewhat large scale. We have had African, Amazonian, and Carolina parrots ; Rosella parroquets, large Bengal parroquets, four species of cockatoos, and two of lories. The lories are magnificent birds, with their scarlet bodies and very long wings and tails of rich metallic green. Curiously enough, however, they are far less seen than any of the others, as they almost always sit buried in the thickest foliage, and have none of the sensibility and intellectual excitement of the cockatoos or parrots. In fact, however, all these birds vanish completely out of sight during great part of the day; many of them, indeed, live in the woods at a distance from the house; but even those who have selected the trees in the garden for their residence would not easily be discovered. You would have supposed that at any rate the white cockatoos would be visible anywhere; but the inclination of all animals is to slip out of the sight of man, and with the shadows of the trees upon them an unpractised eye would rarely discover them. In the morning and evening they come to feed upon hemp-seed, and bread and milk, which is hung in a basket from a tripod; and then, I can assure you, the groups of them are sometimes most beautiful.

Lately we have had great losses, so many have flown away and been shot; but I will read a memorandum which I put down one day, a couple of years ago, of the scene I was watching, and which recurred morning after morning as I sat reading in my study at my house in Surrey. "The parrots' breakfast having been put in the basket, a pair of white cockatoos, who had been anxiously watching the proceedings from the tree above, swooped down and set instantly to work. A Bengal parroquet, with long green wings, presently comes skimming up and flutters for a few minutes almost perpendicularly in the air, exactly in the attitude so often represented by Mr. Gould in his 'Humming-Birds,' with the head and tail curved inwards, and the wings extended. Two or three rose-coloured cockatoos follow, and hang about on the tripod, but do not venture to take their places on the edge of the basket while their fiercer brethren are at work. But presently one of the huge white cockatoos, with yellow crests, comes swinging heavily down over the lawn, putting all the lesser ones to flight in a moment; but they soon gather round again, and a lory, resplendent in red and green, darts through the air, and lights on the top of the tripod, his burnished hues contrasting well with the pure white of the cockatoo below; and the group is completed by a Cornish chough, whose glossy blue-black plumage and orange beak and legs are not the 
least striking of their costumes. He always at once engages in a fierce strife with his rivals ; and his long beak gives him the advantage over them."

I can assure you, ladies and gentlemen, that a spectacle of this sort, which I have witnessed hundreds of times, is one of exquisite beauty, especially in a sparkling winter's morning, with the snow on the ground, when the colours of the birds seem peculiarly gorgeous. Nor do they appear to be injured by the cold: the grey parrots have the sense to get into a house that was built for shelter to them; but none of the others can ever be persuaded to enter it, and live in the woods the whole year through. But even the winter before last, when the thermometer in my neighbourhood fell six degrees below zero, though one cockatoo unaccountably disappeared, all the rest appeared to be as full of life and spirits as possible. In fact, so long as birds are well fed, and are in good health, I do not believe that cold is fatal to them. Their migration depends altogether on food, and not on the fear of cold. Eren the delicate little long-tailed titmouse, and the still more delicate little goldencrested wren, and numbers of other seemingly tender birds remain with us the whole winter through without appearing to suffer. The fact is, that birds have such a wonderful great coat, such a dense mass of down below their feathers, and have also, if I am not mistaken, such a supply of caloric, much beyond that of other animals, that cold rarely kills them-though I do not mean to say that they like it.

It certainly, however, is curious that these African parrots, Bengal parroquets, and lories from the Philippine Islands have never appeared to suffer, even from our frost and snow. I may observe that the gardener declares that the grey parrots foresee a storm, and often take refuge in their glass-house before it comes.

Nothing can be more striking than the contrast between the plumage of the parrots when they first come, and its appearance after they have been flying about for a few weeks, when it acquires a gloss and glitter like that of burnished metal. Variety of food is not less essential to them than abundance, and they also require exercise. Some of them, who cannot fly, or who prefer moping at home, always look woebegone, and are gloomy and irritable, while the industrious Pollies who fly about and help to earn their own livelihood are cheerful, contented, and kindly. It is curious how clearly they have the idea of property and possession. An old parrot, who always sits in the ivy on an old wall, is just as indignant if any other parrot seeks to share in his part of it, as my cook would be if some of you insisted on taking up your residence in my kitchen. Generally, however, they pay the utmost respect to each other's prescriptive rights.

We usually have got our parrots from Mr. Jamrach, who has a shop near Wapping, and who buys all kinds of animals from the ships that come into the docks. His shop is a queer place, and well worth a visit. One day when I was there, he had in his little backyard a crocodile 12 feet long, and another (a baby crocodile, 
which I bought and kept alive for some time) about 18 inches long, and sundry bears, lions, monkeys, racoons, and other animals; while all the rooms of the house itself are given up to birds-mostly of the parrot kind; and the screaming and shrieking is terrific. Every now and then there is a perfect avalanche of the little green parroquets from Australia; and on one occasion Mr. Jamrach had 3000 of them in his bed-rooms. Parrots that can talk fetch a high price; so we rarely buy them, as we don't want pets. Moreover they very soon lose their power of talking when they are out in the woods; but sometimes they learn to imitate other sounds. At my house in Surrey the jackdaws build in boxes placed for them in the gables; and a grey parrot who flies about has learnt to imitate them exactly, while one of the cockatoos can imitate the clucking of a hen so cleverly that no one would conceive that it was not the fowl herself. A large Amazonian parrot, who has been at Northrepps Hall for twenty years, used to be a first-rate talker. He it was who originated the plan of turning the parrots out; for having escaped from his cage, he remained in the oak and beech trees for nearly three months, and only came back when the winter set in, but looking so magnificent that the idea suggested itself of trying the effect of liberty on other parrots as well. After he returned, he amused us very much by walking up and down on the sill of the dining-room window, repeating the phrases of anxious entreaty that had been addressed to him by the maidservants to induce him to come in, exactly imitating their different voices as well as words. On one occasion he nearly frightened a poor woman out of her wits by suddenly plumping down on the top of her head as she was walking along the road. On two or three occasions, strangers, when approaching the house, have been perfectly astounded by hearing what they took for the voices of invisible human beings issuing from the trees over their heads. One of his favourite phrases still is, "I have no wife, but I have to care for my mother."

One of the young cockatoos that was born in the acacia trees disappeared last spring, but returned the other day in a beggarly and ruinous condition, having evidently been nearly starved, but soon recovered his good looks. It is eurious what could have become of him, and how he found his way back after so long an absence. The same thing has occurred with others. One of the large cockatoos deserted my place in Surrey for several months, and was continually seen associating with a flock of rooks some miles away, but at length returned. On one occasion a flock of our parrots flew to a place full twenty-five miles away, and eleven of them were shot. Afterwards five cockatoos were shot all together in the same way.

It is curious what friendships arise between birds, some of which belong to different species. A parroquet and a green parrot were perfectly inseparable; and so, too, at my house in Surrey, I had at one time a flock of eleven grey parrots; but ten of them having got killed, the survivor associated himself with some cockatoos, and for the last few years has invariably flown about in their company. Ann.\&Mag. N. Hist. Ser. 4. Vol. ii. 
One Carolina parrot was frost-bitten in the hard winter of 1860 , and lost both her legs. She looked a deplorable object ever after; but a magnificent parrot took pity on her, and devoted himself to her in a most chivalrous manner, defending her from the attacks of other parrots who would have murdered her, cleaning her feathers, and generally sitting close to her side. The contrast was most ridiculous between the diseased old cripple and the splendid young knight who had this infatuation for her. After some years, however, the cockatoos made a combined attack upon her, a tremendous scrimmage took place, certainly not without the " din of battle," and it ended in the slaughter of the poor old bird.

They are very fond of the under gardener, who feeds them; and he is rarely to be seen at work out in the garden without one or two cockatoos sitting on his head or shoulders. Their arrangement of their hours is a very sensible one. Soon after dawn their voices may be heard from a distant wood, in which most of them sleep. They then come and wait for their breakfast; but the midday hours are always spent in sleep, after which they again seek for food, and come for their supper; but before they go to bed they, like rooks, devote themselves to a regular jollification, the parrots often flying round at a great height in circles, screaming with delight, while the cockatoos fly from tree to tree with their crests erected, shrieking at the top of their sweet voices, especially if they see people in the garden, which always is a great amusement to them. I must confess that some of them, if not all, are mischievous, especially in the way of picking fruit; but we think ourselves more than repaid by the animation they give to the garden, and the exquisite beauty of their colouring.

\section{Note on Dr. Macdonald's Paper on the Dentition of Gasteropods.} By Dr. J. E. Gray, F.R.S.

I think that Dr. Macdonald has committed an error that is common to young naturalists - has mistaken an analogy for an affinity. The form of the lateral teeth of the odontophore is, no doubt, a good specific (and may be generic) character; but I think that Dr. Macdonald's table proves that it is not the character of a family. The character of a family should be derived from the consideration of the whole animal-its form, the form and development of the teeth, and the form of the shell and operculum; and not from any one character, such as the form of the lateral lingual teeth, especially if it brings together in the same family such a series of incongruous genera and separates nearly allied genera as they are separated in Dr. Macdonald's list. Therefore I cannot agree with him that " the lingual dentition appears to be the only appeal," or that the best means for arranging the genera and families is according to the form of the lateral teeth. I think, if any one will consult Dr. Macdonald's plate, he must perceive that the lateral teeth gradually pass from one form to the other; and I cannot conceive any reason why all the forms figured may not belong to the genera of one family. 


\section{$2 \mathrm{BHL}$ Biodiversity Heritage Library}

Buxton, Charles. 1868. "Acclimatization of parrots at Northrepps Hall, Norfolk." The Annals and magazine of natural history; zoology, botany, and geology 2, 381-386. https://doi.org/10.1080/00222936808695824.

View This Item Online: https://www.biodiversitylibrary.org/item/72302

DOI: https://doi.org/10.1080/00222936808695824

Permalink: https://www.biodiversitylibrary.org/partpdf/61351

\section{Holding Institution}

University of Toronto - Gerstein Science Information Centre

\section{Sponsored by}

University of Toronto

\section{Copyright \& Reuse}

Copyright Status: NOT_IN_COPYRIGHT

This document was created from content at the Biodiversity Heritage Library, the world's largest open access digital library for biodiversity literature and archives. Visit BHL at https://www.biodiversitylibrary.org. 